SVU- International Journal of Veterinary Sciences, 4 (2): 76-84, 2021.

Print ISSN: 2535-1826

\title{
Occurrence and characterization of Pseudomonas species isolated from Fish Marketed in Sohag Governorate, Egypt
}

\section{Hadeer A. Abd-El-Maogoud ${ }^{1}$, Abo Baker M. Edris², Ayman H. Mahmoud ${ }^{1}$, Mohamed A. Maky $^{3 *}$}

${ }^{1}$ Biotechnology and Food Control Department, Animal Health Institute, Doki, Giza, Egypt, ${ }^{2}$ Food Control Department, Faculty of Veterinary Medicine, Benha University, 13511, Benha Egypt, ${ }^{3}$ Food Hygiene and Control Department, Faculty of Veterinary Medicine, South Valley University, Qena, 83522, Egypt.

\section{Abstract}

The aims of this study were isolation and characterization of Pseudomonas spp. from fish meat collected from Sohag governorate, Egypt. A total 120 fish samples including frozen mackerel, frozen saurus, chilled Mugil cephalus and chilled Tilapia nilotica (30 of each) were collected from different shops and supermarkets in Sohag governorate. Pseudomonas spp. were isolated from 65\% of the examined samples. The obtained data revealed that the highest count of Pseudomonas was in chilled Tilapia nilotica. The prevalence of Pseudomonas aeruginosa in frozen mackerel, frozen saurus, chilled Tilapia nilotica and chilled Mugil cephalus was 33.3\%, 30\%, $23.3 \%$ and $26.6 \%$ respectively. Furthermore, psychrotrophic count was performed and the results demonstrated that it was the highest in frozen mackerel followed by Tilapia nilotica and the Mugil cephalus showed the lowest count. Furthermore, the occurrence of $\operatorname{opr} L$, $p h z M$ and toxA virulence genes was studied in some selected isolates by PCR. The findings showed that all the selected isolates possessed the virulence genes. This work showed contamination of fish samples with Pseudomonas spp., indicating the importance of applying hygienic measures during handling and storage of fish.

Keywords:

Pseudomonas aeruginosa, Contamination, PCR, Virulence genes.

DOI: 10.21608/svu.2021.64991.1111 Received: February 24, 2021 Accepted: June 11, 2021 Published: June 25, 2021 *Corresponding Author: Mohamed A. Maky E-mail: mohamedmekky@vet.svu.edu.eg

Citation: Abd-El-Maogoud et al., Occurrence and characterization of Pseudomonas species isolated from Fish Marketed in Sohag Governorate, Egypt. SVU-IJVS 2021, 4 (2): 76-84.

Copyright: () Abd-El-Maogoud et al. This is an open access article distributed under the terms of the creative common attribution license, which permits unrestricted use, distribution and reproduction in any medium provided the original author and source are created.

Competing interest: The authors have declared that no competing interest exists. 


\section{Introduction}

Fish and seafood represent an essential and famous food for several parts of the world population and in some countries, fish is considered the main source of animal protein (Allison et al., 2009). Moreover, fish is known as an inexpensive source of protein compared with other protein products like beef and poultry

Various bacterial diseases can infect a large variety of fish and initiate significant financial damage. The loss is related to bad growth, deaths and inferior meat quality. Pseudomonas is one of the most common fish bacterial diseases. Pseudomonas is a part of the usual fish microflora and can be opportunistic and developed into virulent and disseminated in distressed fish. Pseudomonas plays a role in the process of fish decomposition and in some circumstances, they may become human pathogens and induce infection particularly human infection caused by Pseudomonas aeruginosa (Zilberberg and Shorr, 2009). Pseudomonas aeruginosa can cause serious diseases in exhausted fish including, hemorrhagic septicemia, congested kidney, gill necrosis and friable liver (Ardura et al., 2013).

The occurrence of Pseudomonas in fish has been reported in many countries (Yagoub 2009; Ardura et al., 2013; Algammal et al., 2020). Currently, extreme efforts for diagnosis of Pseudomonas aeruginosa have been recognized, not only because of its economic value, but because of its public heath significance. Pseudomonas spp. is currently listed as a foodborne illness that affects consumers through consumption and handling infected fish (Gram et al., 2002).

Sohag is placed on the western side of the Nile, on a productive soil region. People in Sohag are accustomed to purchasing raw fish from markets and street vendors rather than purchasing cooked fish. The purpose of the present work was to study the existence of Pseudomonas spp. in sample of commercial fish offered in Sohag market, Egypt. In addition to, genotypic analysis of certain virulence genes was conducted to examine their probability of bacterial pathogenicity.

\section{Materials and methods}

\section{Fish sampling:}

A total of 120 random samples of local frozen Mackerel, frozen Saurus chilled Mugil Cephalus and chilled Tilapia nilotica (30 of each) were randomly collected from various fish markets located at Sohag governorate, Egypt. The samples were placed in an ice box until performing bacteriological examination in the laboratory.

\section{Enumeration and identification of Pseudomonas:}

Twenty-five $\mathrm{g}$ from flesh of fish was homogenised with $225 \mathrm{ml}$ of peptone water, serial decimal dilutions were carried out. $100 \mu \mathrm{L}$ of each dilution was spreads Pseudomonas agar base media and incubated at $25^{\circ} \mathrm{c}$ for $48 \mathrm{~h}$ and the devolved colonise were counted (Roberts and Greenwood, 2003) Furthermore, colonises were collected and purified and subjected for identification by Gram stain and conducting biochemical tests as described by Quinn et al. (2002), Austin and Austin (2007).

\section{Enumeration and identification of psychrotrophic bacteria:}

One-hundred $\mu \mathrm{L}$ of each dilution was spread onto plate count agar and incubated at $7^{\circ} \mathrm{c}$ for 10 days. Furthermore, isolation and identification of Gram-positive and Gram-negative bacteria was performed as described by Quinn et al. (2002), Barrow and Feltham, (2004). Briefly, samples were inoculated into nutrient broth at $37^{\circ}$ for 24 hours, then a loopful was streaked into blood agar for isolation of Gram-positive 
bacteria, Baird Parker Agar for isolation of Staphylococci spp., tryptone Soya agar for isolation of Bacillus spp., MacConkey agar for isolation of Gram-negative bacteria. Identification of bacteria was performed according to their colony features, Gram's staining and various biochemical reactions.

\section{Molecular typing of the virulence genes of the isolated Pseudomonas aeruginosa:}

Some strains of Pseudomonas aeruginosa were selected for detection oprL, toxA and phzM. DNA was extracted by boiling method as described by Reischl et al. (2002). The three sets of primers (Table 1) were used for detection of virulence genes. Each PCR reaction was done in a total volume of $20 \mu \mathrm{l}$ as follows: $2 \mu \mathrm{l}$ of template DNA, $0.6 \mu \mathrm{MgCl} 2,0.4$ $\mu \mathrm{l}$ of each primer, $0.2 \mu \mathrm{ldNTP}, 2 \mu \mathrm{l}$ of $10 \mathrm{x}$ PCR buffer, $0.5 \mu 1$ of Taq DNA polymerase $(5 \mathrm{U} / \mu \mathrm{l})$ (SinaClon, Tehran, Iran) and $13.9 \mu \mathrm{l}$ of Milli-Q water. The PCR condition was an initial denaturation at $95^{\circ} \mathrm{c}$ for 5 minutes, then processed into 35 cycles each one was denaturation at $95^{\circ} \mathrm{C}$ for 30 second, annealing at $55^{\circ} \mathrm{c}$ for 35 seconds and extension at $72{ }^{\circ} \mathrm{c}$ for 30 second. A PCR reaction without any DNA was utilized as a negative control, while a reference strain of Pseudomonas aeruginosa gladly given by the Animal Health Institute in Giza, Egypt, was utilized as positive control.

Table 1. Primers used for the amplification of different virulence genes among Pseudomonas aeruginosa isolates.

\begin{tabular}{llll}
\hline Target gene & Primer sequence & Size & Reference \\
\hline oprL & F: CGGGCGTGCTGATGCTCGTAT & $709 \mathrm{bp}$ & Vijayakumar et al., \\
& R: GCGCGAG GAACGTCAGGACAC & & 2011 \\
& & & \\
toxA & F:GACAACGCCCTCAGCATCACCAGC & $396 \mathrm{pb}$ & Verove et al., 2012 \\
& R:CGCTGGCCCATTCGCTCCAGCGCT & & \\
phzM & F: CCGTCGAGAAGTACATGAAT & $857 \mathrm{pb}$ & Sambrook et al., \\
& R: CATAGTTCACCCCTTCCAG & & 1989 \\
\hline
\end{tabular}

Results

\section{Bacteriological assay:}

The bacteriological examination for the occurrence of Pseudomonas revealed that Pseudomonas spp. were isolated from $65 \%$ of examined samples. Mugil cephalus showed a high contamination level $(73.3 \%)$ followed by Tilapia nilotica $(66.6 \%)$ while saurus demonstrated a low contamination level (56.6\%). Notably, the examined chilled Tilapia nilotica showed significantly greater Pseudomonas count than chilled Mugil cephalus, whereas frozen mackerel was significantly higher than the frozen saurus samples (Table 2).

Table 2: Statically analytical results of total Pseudomonas count (CFU/g) of the examined fish samples $(\mathrm{n}=30)$. Various letters indicated a statistically significant difference between the means at $p<0.05$

\begin{tabular}{lccccc}
\hline Samples & \multicolumn{3}{c}{ Positive samples } & \multicolumn{2}{c}{ Count CFU/g } \\
& No. & \% & Min. & Max. & Mean \pm SE \\
\hline Frozen Mackerel & 19 & 63.3 & $2.9 \times 10^{2}$ & $3.5 \times 10^{5}$ & $8 \times 10^{4 \mathrm{a}} \pm 2.5 \times 10^{4}$ \\
Frozen Saurus & 17 & 56.6 & $4.7 \times 10^{2}$ & $1.3 \times 10^{4}$ & $5 \times 10^{3 \mathrm{~b}} \pm 1.1 \times 10^{3}$ \\
Chilled Tilapia nilotica & 20 & 66.6 & $1.6 \times 10^{2}$ & $5.4 \times 10^{5}$ & $1 \times 10^{5 \mathrm{a}} \pm 3.8 \times 10^{4}$ \\
Chilled Mugil cephalus & 22 & 73.3 & $1.4 \times 10^{2}$ & $1.7 \times 10^{4}$ & $5 \times 10^{3 \mathrm{~b}} \pm 1.1 \times 10^{3}$ \\
\hline
\end{tabular}


The isolated Pseudomonas spp. were identified into Pseudomonas aeruginosa, Pseudomonas diminuta and Pseudomonas fluorescenes. The results of the obtained data in our study, revealed that Pseudomonas aeruginosa was the highly isolated from Mackerel followed by saurus,
Mugil cephalus and Tilapia nilotica. Pseudomonas fluorescenes and Pseudomonas diminuta were also isolated and identified with various percentages. However, some species couldn't be identified by the available biochemical tools (Table 3 ).

Table 3: Incidence of isolated Pseudomonas species in the examined fish samples $(\mathrm{n}=30)$

\begin{tabular}{lllllllll}
\hline Pseudomonas spp. & \multicolumn{4}{c}{ Frozen fish } & \multicolumn{4}{c}{ Chilled fish } \\
& Mackerel & Saurus & T. nilotica & M. cephalus \\
\hline & No & $\%$ & No & $\%$ & No & $\%$ & No & $\%$ \\
Pseudomonas aeruginosa & 10 & 33.3 & 9 & 30 & 7 & 23.3 & 8 & 26.6 \\
Pseudomonas diminuta & 3 & 10 & 3 & 10 & 2 & 6.6 & 5 & 16.6 \\
Pseudomonas fluorescenes & 4 & 13.3 & 3 & 10 & 2 & 6.6 & 1 & 3.3 \\
Unidentified species & 2 & 6.6 & 2 & 6.6 & 9 & 30 & 8 & 26.6 \\
\hline
\end{tabular}

Furthermore, the psychrotrophic bacterial count was conducted. The results showed that, the frozen mackerel samples showed significantly high contamination level with a mean value $1.3 \times 10^{6} \mathrm{CFU} / \mathrm{g}$, while chilled Mugil cephalus had the lowest count (Table 4).

Table 4: Statically analytical results of total psychrotrophic bacterial count (CFU/g) of examined fish samples $(n=30)$. Various letters indicated a statistically significant difference.

\begin{tabular}{llcc}
\hline \multicolumn{1}{c}{ Samples } & \multicolumn{1}{c}{ Minimum } & $\begin{array}{c}\text { Count CFU/g } \\
\text { Maximum }\end{array}$ & Mean \pm SE \\
\hline Frozen Mackerel & $6.6 \times 10^{3}$ & $7.1 \times 10^{6}$ & $1 \times 10^{6 \mathrm{a}} \pm 4.1 \times 10^{5}$ \\
Frozen Saurus & $1.2 \times 10^{3}$ & $6.7 \times 10^{5}$ & $1 \times 10^{5 \mathrm{~b}} \pm 4.1 \times 10^{4}$ \\
Chilled Tilapia nilotica & $2.4 \times 10^{3}$ & $3.5 \times 10^{6}$ & $8 \times 10^{5 \mathrm{a}} \pm 2.2 \times 10^{5}$ \\
Chilled Mugil cephalus & $1.1 \times 10^{3}$ & $2.3 \times 10^{5}$ & $7 \times 10^{4 \mathrm{c}} \pm 1.5 \times 10^{4}$ \\
\hline
\end{tabular}

The Predominant Gram-positive bacteria have been identified among psychrotrophic bacteria. The result showed the occurrence of Staphylococcus spp. with high level followed by Micrococcus spp. whereas Bacillus spp. were identified by low incidence. Furthermore, Gramnegative bacteria, such as Aeromonas spp. and Achromobacter spp. were identified with various contamination level as displayed (Table 5). 
Table 5: Incidence of identified psychrotrophic bacteria isolated from examined fish samples $(n=30)$.

\begin{tabular}{|c|c|c|c|c|c|c|c|c|}
\hline \multirow{3}{*}{ Microorganisms } & \multicolumn{4}{|c|}{ Frozen fish } & \multicolumn{4}{|c|}{ Chilled fish } \\
\hline & \multicolumn{2}{|c|}{ Mackerel } & \multicolumn{2}{|c|}{ Saurus } & \multicolumn{2}{|c|}{ Tilapia nilotica } & \multicolumn{2}{|c|}{ Mugil cephalus } \\
\hline & No. & $\%$ & No. & $\%$ & No. & $\%$ & No. & $\%$ \\
\hline \multicolumn{9}{|c|}{ Gram-positive bacteria } \\
\hline Staphylococcus spp. & 10 & 33.3 & 3 & 10 & 11 & 36.6 & 12 & 40 \\
\hline Micrococcus spp. & 5 & 16.6 & 4 & 13.3 & 5 & 16.6 & 11 & 36.6 \\
\hline Bacillus spp. & 2 & 6.6 & 0 & 0 & 3 & 10 & 1 & 3.3 \\
\hline \multicolumn{9}{|c|}{ Gram-negative bacteria } \\
\hline Aeromonas spp. & 5 & 16.6 & 7 & 23.3 & 5 & 16.6 & 6 & 20 \\
\hline Achromobacter spp. & 8 & 26.6 & 11 & 36.6 & 0 & 0 & 11 & 36.6 \\
\hline
\end{tabular}

\section{Molecular detection of virulence genes.}

Some isolates among Pseudomonas aeruginosa were selected for further study on the occurrence of oprL, phzM and toxA virulence genes. The results showed that all selected isolates harbored $o p r L, p h z M$ and toxA virulence genes as shown in Fig.1, Fig. 2 and Fig.3, respectively.

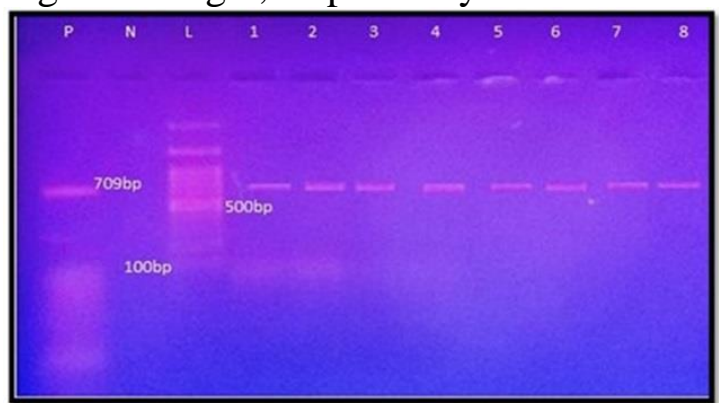

Fig. 1. DNA products from PCR reaction of amplification oprL gene in Pseudomonas aeruginosa. A PCR amplicons corresponding to $709 \mathrm{bp}$ were obtained. P: positive control; N: negative control, L: ladder; lan1-lan8: +ve isolates.

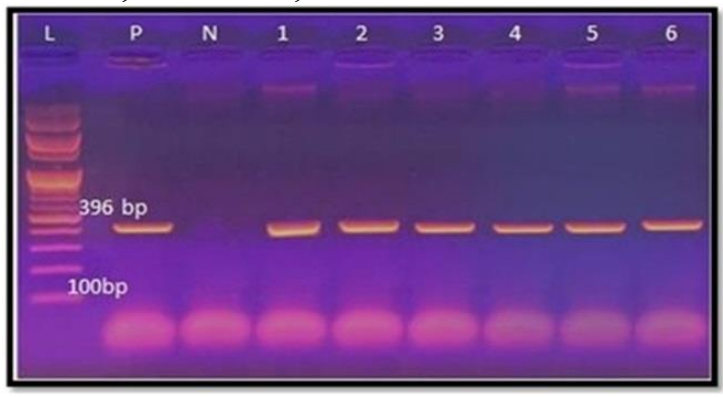

Fig. 2. DNA products from PCR reaction of amplification tox $A$ gene in Pseudomonas aeruginosa. A PCR amplicons corresponding to $396 \mathrm{bp}$ were obtained. L: ladder; P: positive control; N: negative control; lan1-lan6: +ve isolates.

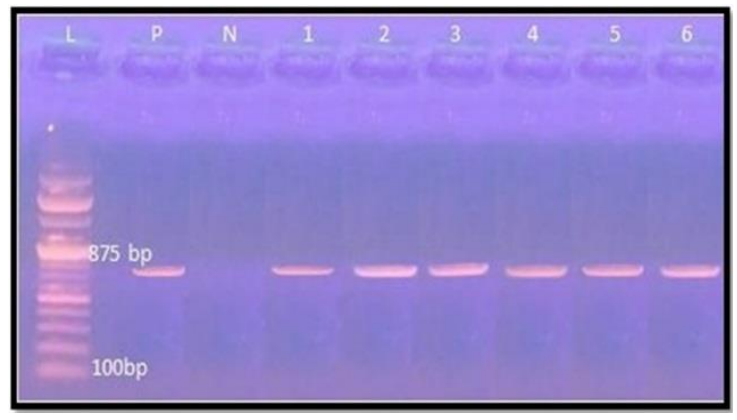

Fig. 3. DNA products from PCR reaction of amplification phzM gene in Pseudomonas aeruginosa. A PCR amplicons corresponding to $875 \mathrm{bp}$ were obtained. L: ladder; P: positive control; N: negative control; lan1-lan6: positive isolates.

\section{Discussion:}

Bacteriological assessment of fish for the occurrence of Pseudomonas spp. has considerable significance as they are markers of meat quality as well, they may induce foodborne illness. In the current work, a total of 120 fish samples, including 
frozen Mackerel, frozen Saurus, chilled Mugil Cephalus and chilled Tilapia nilotica (30 of each) were collected from various shops and markets at Sohag governorate, Egypt, for evaluation the existence of Pseudomonas spp. the results showed that $65 \%(78 / 120)$ samples were contaminated with Pseudomonas spp. Our findings were lower than those obtained by Abd El-Aziz (2015), who reported that all examined fish samples collected from Assiut city, Egypt was contaminated with Pseudomonas spp. Duman et al (2021) isolated ninety Pseudomonas strains from fish farms in Turkey and classified into 12 species and seven new Pseudomonas species were reported.

The obtained data in our study revealed that the highest Pseudomonas counts was Mackerel followed by Saurus in frozen fish samples, while in fresh chilled fish samples were Tilapia nilotica followed by Mugil cephalus with significant difference. The variation in the results between different species may be due to the difference in hygiene measures applied during catching, handling, freezing, storage and method of thawing in fish as mentioned by Salem et al. (2018).

The occurrence of Pseudomonas aeruginosa in the examined samples may be attributed to the fact that this specie commonly found in human, animals, plants and are a zoonotic important. Lower results were obtained by Benie et al. (2016), Ibrahim et al. (2016) and Salem et al. (2018).

Notably, mackerel samples showed the highest contamination level with psychrotrophic bacteria. These results may attribute to that the Mackerel contains high amount of fat and oils that favour growth of bacteria (Salem et al., 2018). The psychrotrophic count in Saurus spp. came in accordance with those reported by ElShafey (2014) and higher results obtained by El-Sayed (2016) and El-Noby (2002) in frozen Mugile Cephalus and Mackerel. However, lower results were obtained by Salem et al. (2018)

Furthermore, psychrotrophic bacteria were differentiated into Gram- positive bacteria including Staphylococcus spp., Micrococcus spp. and Bacillus spp. as well Gram-negative bacteria were identified including Aeromonas spp. and Achromobacter spp. Nearly similar results were obtained by El-Hady and Samy (2011); Bahurmiz et al. (2016) and ElSayed (2016).

In the present work, the PCR results showed that all selected isolates were positive for $o p r L, p h z M$ and toxA virulence genes. Similar result was reported by Khattab et al (2015). L- lipoproteins mean the outer membrane protein associated with Pseudomonas aeruginosa that allow the bacterium to withstand the disinfectant and antibiotics. oprL is limited to Pseudomonads, so it could be a trustworthy maker utilized in recognition and pathogenicity assessment (Remans et al., 2010). Exotoxin A is an extracellular protein of pathogenic Pseudomonas aeruginosa and works by prevention of protein-synthesis in the cell (Aljebory et al., 2018). Furthermore, the presence of phzM in studied strains suggested their capability to secret a phenazine toxin, which improves their existence and establishment in inverse conditions (Bradbury et al., 2010; Cezairliyan et al., 2013).

In brief, Pseudomonas aeruginosa is one of the main emerging pathogens usually recovered from fish. The current work has shown that fish sold in Sohag governorate, Egypt was contaminated with Pseudomonas species. Enhancing the hygienic status of the fish preparation areas and the necessity for proper sanitation measures among fish staffs are required. 


\section{Conflict of interest statement}

The authors declare that there are no conflicts of interest regarding publication of this article.

\section{Ethical Approval}

The animal experimental protocols were approved by the Animal Care and Use Committee of Animal Health Institute, Doki, Giza, Egypt and by the Animal Care and Use Committee of South Valley University, Egypt.

\section{References}

Abd El-Aziz, D. (2015). Detection of Pseudomonas spp. in chicken and fish sold in markets of assiut city, Egypt. Journal of Food Quality and Hazards Control, 2: 86-89.

Algammal A, Mabrok M, Sivaramasmy E, Youssef F, Atwa M, El-kholy A, Hetta H, Hozzein W (2020). Emerging MDR-Pseudomonas aeruginosa in fish commonly harbor $o p r \mathrm{~L}$ and tox $\mathrm{A}$ virulence genes and $b^{b} a_{\mathrm{teM}}, \quad b l a_{\mathrm{ctX}-\mathrm{M}}, \quad$ and tet $\mathrm{A}$ antibiotic-resistance genes. Scientific Reports, 10:15961

Aljebory IS (2018). PCR detection of some virulence gene of Pseudomonas aeruginosa in Kirkuk city, Iraq. Pharmaceutical Sciences and Research, 10: 1068-1071.

Allison E, Perry A, Badjeck C (2009). Vulnerability of national economies to the impacts of climate change on fisheries. Fish and Fisheries, 10(2): 173-196.

Ardura A, Linde AR, Garcia-Vazquez E (2013). Genetic detection of Pseudomonas spp. in commercial amazonian fish. International
Journal of Environmental Research and Public Health, 10: 3954-3966.

Austin, B., Austin, D.A. 2007. Bacterial Fish Pathogens, Diseases of Farmed and Wild Fish $4^{\text {th }}$ Ed, Praxis Publishing Ltd, Chichester UK

Bahurmiz M, Ahmad R, Ismail N, Frederick A, Shaida-Fariza S (2016). Antimicrobial activity of various plant extracts on Pseudomonas spp. associated with spoilage of chilled fish. Turkish Journal of Agriculture - Food Science and Technology 4(11): 1017-1023.

Barrow GI, Feltham RKA (2004). Cowan and Steel's Manual for the Identification of Medical Bacteria. UK: Cambridge University, pp.39725.

Benie C, Dadie A, Guessennd N, Kouame $\mathrm{N}$, Yobouet B, Aka S, Koffi M, Dosso M (2016). Prevalence and diversity of Pseudomonas spp. isolated from beef, fresh and smoked fish in Abidjan, Côte d'Ivoire. Journal of Food and Dairy Technology. 4 (4): 52-61.

Bradbury RS, Roddam L, Merritt A, Reid DW, Champion AC (2010). Virulence gene distribution in clinical, nosocomial and environmental isolates of Pseudomonas aeruginosa. Journal of Medical Microbiology, 59: 881890.

Cezairliyan B, Vinayavekhin N, Grenfelllee D, Yuen, G, Saghatelian A, Ausubel F (2013). Identification of Pseudomonas aeruginosa phenazines that kill Caenorhabditis elegans. PLOS Pathogens, 9: 1-9.

Duman, M., Mulet, M., Altun, S., Saticioglu, I., Ozdemir, B., Ajmi, 
N., Lalucat, J., Garcia-valdes, E. 2021. The diversity of Pseudomonas species isolated from fish farms in Turkey. Aquaculture, 535.

El-Hady MA, Samy AA (2011). Molecular typing of Pseudomonas spp. isolated from some cultured fishes in Egypt. Global Veterinaria, 7 (6): 576-580.

El-Noby M (2002). Psychotropic bacteria in marketed fish. M. V. Sc. Thesis. Dep. Food Control. Fac. Vet. Med. Zagazig University.

EL-Sayed H (2016). Bacterial Evaluation of some fresh and frozen fish. M. V. Sc. Thesis, Fac. Vet. Med., Benha Univ.

El-shafey WS (2014). Psychrotrophs in frozen fish. M. V. Sc. Thesis, Fac. Vet. Med, Banha University.

Gram L, Ravn L, Rasch M, Bruhn J, Christensen A, Givskov M (2002). Food spoilage - -interactions between food spoilage bacteria. International Journal of Food Microbiology, 78, 79-97.

Ibrahim HM, Reham AA, Shawkey NA, Mohammed HE (2016): Bacteriological Evaluation of Some Fresh and Frozen fish. Benha Veterinary Medical Journal, 31(1): 24-29.

Khattab, M., Nour, m., Elsheshtawy. (2015). Genetic Identification of Pseudomonas aeruginosa virulence genes among different isolates. Journal of Microbial \& Biochemical Technology 7(5): 274-277.

Quinn PJ, Carter ME, Markey B, Carter GR (2002). Clinical Veterinary
Microbiology. Grafos: Mosby International, pp.6-346. 2

Reischl U, Youssef M, Kilwinski J, Lehn N, Zhang W, Karch H, Strockbine, N (2002). Real-time fluorescence PCR assays for detection and characterization of Shiga toxin, intimin, and enterohemolysin genes from Shiga toxin-producing Escherichia coli. Journal of Clinical Microbiology, 40: 2555-2565.

Remans K, Vercammen K, Bodilis J, Cornelis, P. (2010). Genome-wide analysis and literature-based survey of lipoproteins in Pseudomonas aeruginosa. Microbiology, 156: 2597-2607.

Roberts D., Greenwood M. (2003). Practical food microbiology. $3^{\text {rd }}$ edition. Blackwell Publishing Ltd, UK. 273-274

Salem A, Osman I, Shehata S (2018). Assessment of psychrotrophic bacteria in frozen fish with special reference to Pseudomonas spp. Benha Veterinary Medical Journal, 34 (2):140-148.

Sambrook J, Fritsch E, Montias T (1989). Molecular Biology. In: Molecular cloning. Laboratory manual, $2^{\text {nd }} \mathrm{Ed}$. Cold Spring Harbor Laboratory press, USA

Verove J, Bernarde C, Bohn Y (2012) Injection of Pseudomonas aeruginosa Exo toxins into host cells can be modulated by host factors at the level of translocon assembly and/or activity. Plos One, 7(1):e30488

Vijayakumar R, Venkatesa K, Manoharan C (2011). Molecular diagnosis of Pseudomonas aeruginosa contamination in ophthalmic 
viscosurgical devices. International Journal of Research in Pharmaceutical Sciences, 2(4): 579584.

Yagoub SO (2009). Isolation of Enterobacteriaceae and Pseudomonas spp. from raw fish sold in fish market in Khartoum state. Journal of Bacteriology Research. 1: 85-88.

Zilberberg MD, Shorr AF (2009).

Epidemiology of healthcareassociated pneumonia (HCAP). Seminars in Respiratory and Critical Care Medicine, 30: 10-15. 